\title{
DISSOLVING PULP FROM KENAF BY BIO-BLEACHING PROCESS
}

\author{
Susi Sugesty ${ }^{1}$, Yusup Setiawan \\ Centre for Pulp and Paper (CPP) \\ Jl. Raya Dayeuhkolot No. 132, Bandung-Indonesia \\ ${ }^{1}$ sugestyms@yahoo.com
}

Diterima : 10 Juni 2013, Revisi akhir : 14 November 2013, Disetujui terbit : 02 Desember 2013

\section{PULP DISSOLVING DARI KENAF MENGGUNAKAN PROSES BIO-BLEACHING}

\begin{abstract}
ABSTRAK
Kenaf berasal dari daerah Jawa Timur Malang - berusia empat sampai lima bulan dan digunakan sebagai bahan baku dissolving pulp. Morfologi dan komponen kimia kenaf dianalisis berdasarkan Standar Nasional Indonesia (SNI). Serat kenaf memiliki panjang serat rata-rata 2,59 $\mathrm{mm}$ untuk batang dan 3,63 $\mathrm{mm}$ untuk kulit pohon, termasuk kedalam kelompok serat panjang dengan panjang serat $>1,60 \mathrm{~mm}$. Kenaf mengandung alpha selulosa sebesar $45,45 \%$ untuk kulit dan 39,46\% untuk batang. Kenaf dipotong-potong dengan panjang 3 sampai dengan $5 \mathrm{~cm}$. Sebelum pemasakan, dilakukan prahidrolisa menggunakan air dan asam encer $\left(0,4 \% \mathrm{H}_{2} \mathrm{SO}_{4}\right)$ untuk melunakkan serpih kenaf dan membuat ikatan pentosan (hemiselulosa) menjadi lemah, dengan merendamnya dalamair dan $0,4 \% \mathrm{H}_{2} \mathrm{SO}_{4}$ dengan rasio $1: 5$ pada suhu $135^{\circ} \mathrm{C}$ selama 2 jam. Selanjutnya dilakukan pemasakan dengan proses kraft menggunakan Alkali Aktif (AA) sebesar 16\% dan sulfiditas (S) sebesar 28\%. Rasio bahan baku dan larutan pemasak adalah $1: 5$ pada suhu $160^{\circ} \mathrm{C}$ selama 3 jam. Proses pemutihan pulp dilakukan dalam lima tahap terdiri dari $\mathrm{XOD}_{0} \mathrm{E}_{0} \mathrm{D}_{1} \mathrm{D}_{2}$ (Xilanase, Oksigen delignifikasi, Klorin dioksida, Oksigen Ekstraksi, Klorin dioksida 1, Klorin dioksida 2). Proses pemutihan pada tahap X menggunakan enzim xilanase yang dikenal dengan bio-bleaching. Setiap tahap dicuci dengan air panas sampai bersih. Dissolving pulp yang diperoleh dianalisis derajat cerah, kadar selulosa alfa dan komponen kimia lainnya sesuai SNI. Dissolving pulp mempunyai viskositas yang sangat tinggi, ini berarti bahwa proses pemutihan pulp tidak banyak menyebabkan terjadinya degradasi selulosa.
\end{abstract}

Kata kunci: bio-bleaching, dissolving pulp, prehidrolisa, kenaf, xilanase

\section{ABSTRACT}

The kenaf taken from Malang-East Java was four to five months old and used as the raw material of dissolving pulp. Morphology and chemicals content of kenaf was analyzed based on Indonesian National Standard (SNI). Kenaf fibre has the fibre length average of $2.59 \mathrm{~mm}$ for stem and $3.63 \mathrm{~mm}$ for bast and it is classified on the long fiber, fibre length $>1.60 \mathrm{~mm}$. It contains alpha cellulose in the amount of $45.45 \%$ for bast and $39.46 \%$ for stem. Kenaf was cut with the length of 3 to $5 \mathrm{~cm}$ to make chips. Before cooking, pre-hydrolyzed using water and dilute acid $\left(0.4 \% \mathrm{H}_{2} \mathrm{SO}_{4}\right)$ was done to remove pentosan (hemicellulose) by soaking chips in water and $0.4 \% \mathrm{H}_{2} \mathrm{SO}_{4}$ in the ratio of $1: 5$ at temperature of $135^{\circ} \mathrm{C}$ for 2 hours. The results was mixed with cooking liquor which contains Active Alkali (AA) of $16 \%$ and Sulfidity (S) of $28 \%$. Ratio of raw material and cooking liquor was $1: 5$ at temperature of $160^{\circ} \mathrm{C}$ for 3 hours. Bleaching process was done in the five stages consisted of $\mathrm{XOD}_{0} \mathrm{E}_{0} \mathrm{D}_{1} \mathrm{D}_{2}$ (Xylanase, Oxygen delignification, Chlorine Dioxide, Oxygen Ectraction, Chlorine Dioxide $1^{\text {st }}$, Chlorine Dioxide $\left.2^{\text {nd }}\right)$. Bleaching process in the stage of $\mathrm{X}$ use xylanase enzyme (bio-bleaching). Every stage was washed with hot soft water up to neutral $\mathrm{pH}$. Dissolving pulp was analyzed for brightness, alpha cellulose content and other chemicals content. Pulp viscosity is very high, which means that the pulp bleaching process is not much cause degraded cellulose

Keywords: bio-bleaching, dissolving pulp, pre-hydrolyzed, kenaf, xylanase 


\section{INTRODUCTION}

Wood demand from industrial forest plantations for pulp raw material is still not fulfilled yet due to the shrinking of the industrial forest plantations areas of and decreased productivity as well as the wood converted into woodworking raw materials (Sudomo et al., 2007). Seeing this reality, there is alternative which is very possible to fill the shortage of pulp raw material by using kenaf plants (Hibiscus cannabinus L.). Kenaf plants is one of long fiber sources of non-wood having advantages compared to forest wood such as very short age between $4-5$ months. It can be planted at least twice a year (Sudjindro, 2001). Kenaf can be used as a substitute NUKP (Needle Unbleached Kraft Pulp) or NBKP (Needle Bleached Kraft Pulp) in the paper making (Rosli et al., 2009; Mosello et al., 2009). Based on its fibre morphology and chemical composition, kenaf is a good raw material for pulp. Kenaf stem consists of two distinct parts i.e. bast and wood core core. Bast of kenaf contains fibre ropes as many as $35-40 \%$ by weight. Whereas section wood core containing short fibre as many as 60 - $65 \%$. Kenaf can be processed using whole stalk producing pulp with the quality similar as pulp made from leaf wood. Bleached pulp made from kenaf stems cooked with the soda-anthraquinone process with Active Alkali (AA) of $17 \%$ and Anthraquinone (aq) $0.1 \%$ can meet all the requirements for NBKP (Pratiwi et al., 2002).

Dissolving pulp is a high-grade cellulose pulp, with low contents of hemicellulose, lignin and resin. This very clean pulp is well suited as a raw material for different kinds of cellulose products, such as viscose. Production of dissolving pulp is today mainly done by acid sulfite and prehydrolysis kraft processes (Al-Dajani and Tschirner, 2008; Li et al., 2010). The pulping process has to dissolve the main bulk of the lignin and modify the residual lignin for successful bleaching. Bleaching then has to remove this residual and increase the pulp brightness and cleanliness. The final result should be cellulose as free as possible from lignin and hemicelluloses as well as extractible.

During kraft pulping, the presence of hydrogen sulfide ions greatly facilitates delignification because of their strong nucleophilicity in comparison with hydroxyl ions. For this reason, lignin undergoes more or less drastic degradation reactions resulting from the liberation of phenolic hydroxyl groups in the simultaneous increase in hydrophilicity of lignin fragments. Most of these depolymerized fragments are thus water-soluble and dissolved in the cooking liquor as sodium phenolates. The term "kraft lignin" (in the case of soda pulping, "alkali lignin") is usually referred to as the soluble lignin degradation products in black liquor, and their structures markedly differ from those of the native lignin and the respective residual pulp lignin ("residual lignin").

Delignification in modern bleaching sequences is conducted in the form of ECF processes by application of chlorine dioxide followed by alkaline extraction. In pulp bleaching, bleaching chemicals are a key process to any pulp mill in order to get bleached pulp. This process use Elemental Chlorine Free (chlorine dioxide/ $\mathrm{ClO}_{2}$ ) to pulp bleaching process. Unfortunately, chemicals bleaching react with organic carbon compounds producing toxic compounds of chlorinated hydrocarbons released into environment with the wastewater from the pulp mill if use chlorine $\left(\mathrm{Cl}_{2}\right)$ to bleached pulp. These chlorinated hydrocarbons compounds, such as dioxin, is highly toxic chemicals called organochlorines, which are basically poisons.

Biotechnology can play a major role in establishing the new, technologically advanced and effective processes (Kumar et al., 2009; Russomanno dan Sarkanen, 1998). Xylanase has been found to be effective in reducing chlorine dosage requirement in pre-bleaching process of kraft pulp (Raghukumar et al., 2005). Other applications proposed for xylanase include debarking, refining pulp fibers and preparing dissolving pulps (Christov et al., 1996; Ibarra et al., 2010). If kraft pulps are pre-bleached with xylanase, the $\mathrm{ClO}_{2}$ required to achieve a given degree of bleaching on the delignification of unbleached softwood and hardwood kraft pulps is lower, which reduce organo-chlorines discharges (Saleem dan Akhtar, 2002; Tremblay dan Archibald, 1993; Viikari et al., 1994). The pulp and paper industry is modifying its pulping, bleaching and effluent treatment technologies to reduce the environmental impact of mill effluents (Tremblay dan Archibald, 1993).

The use of kenaf wood from industrial forest plantations is generally used for the manufacture of paper pulp type. To diversify the use of kenaf wood, conditions optimization of dissolving pulp making is necessary. Effect of acid and water use in the pre-hydrolysis process of kenaf and 
effect the use of xylanase in bleaching process of unbleached pulp to the quality of dissolving pulp produced is also presented.

\section{MATERIALS AND METHOD}

Kenaf used in the making of dissolving pulp is taken from plantation at Malang district, East Java. Dissolving pulp process making is consisted of:

1. Raw material preparation

Kenaf was cut to the length of $3-5 \mathrm{~cm}$ and was dried in the open air to maintain a uniform moisture content.

2. Pre-hydrolysis process

Pre-hydrolysis experiments of kenaf were conducted in two pre-hydrolysis conditions that are by using water and $0.4 \%$ $\mathrm{H}_{2} \mathrm{SO}_{4}$ solution. Pre-hydrolysis process of kenaf was carried out in an autoclave by immersing approximately 400 grams of wood chip in water and $0.4 \% \mathrm{H}_{2} \mathrm{SO}_{4}$ solution with the ratio of each ingredient with a pre-hydrolysis solution of 1 to 4 at a temperature of $135^{\circ} \mathrm{C}$ for 2 hours. After completing of pre-hydrolysis, the remaining water and the solution were removed by filtering and the pre-hydrolysis product was then cooked.

3. Cooking process

Cooking process of kenaf chip is done by using active alkali (AA) of $16 \%$, sulfidity (S) of $28 \%$ with a ratio of 1 to 5 at the temperature of $160^{\circ} \mathrm{C}$ for 3 hours. During cooking, both temperatures in the autoclave and in the digester room were controlled. After cooking, the pulp was washed on the flat screen and the pulp fibres were refined in pin shredder. Unbleached pulp produced was then pressed and was determined the Kappa number and the yield.
4. Bleaching process

Bleaching of unbleached pulp was performed without the use of chlorine with five stages, namely $\mathrm{XOD}_{0} \mathrm{E}_{\mathrm{O}} \mathrm{D}_{1} \mathrm{D}_{2}$ (xylanase, oxygen delignification, chlorine dioxide, oxygen extraction, $1^{\text {st }}$ chlorine dioxide, $2^{\text {nd }}$ chlorine dioxide). Pulp from each bleaching stage was washed with hot soft water until the neutral $\mathrm{pH}$. Bleaching process conditions is shown in Table 1.

Morphology of kenaf was analyzed by the method of procedure Franklin U.S. Forest Products Research Laboratory, Department of Agriculture and the Indonesian National Standard. Chemical properties of kenaf were analyzed by Indonesian National Standard (SNI). Unbleached and bleached dissolving pulp produced was analyzed by Indonesian National Standard (SNI 0938-1989-A).

\section{RESULTS AND DISCUSSION}

\section{Raw Materials and Characterization}

Kenaf plants (Figure 1a) is one of long fiber sources of non-wood having advantages compared to forest wood such as very short age between 4 - 5 months. It can be planted at least twice a year (Sudjindro, 2001). Kenaf stem (Figure 1b) consists of two distinct parts i.e. bast and wood core. Bast of kenaf contains fibre ropes as many as $35-40 \%$ by weight. Kenaf plants used in the investigation of dissolving pulp making in the cooking laboratory of Center for Pulp and Paper (CPP) is one of superior type of kenaf obtained in the form of stem from kenaf farmers located at Malang district, East Java.

Before cooking, the size of kenaf chip was classified by using a vibrating sieve which

Table 1. Bleaching Process Condition

\begin{tabular}{lcccccc}
\hline \multicolumn{1}{c}{ Parameter } & $\mathrm{X}$ & $\mathrm{O}$ & $\mathrm{D}_{0}$ & $\mathrm{E}_{0}$ & $\mathrm{D}_{1}$ & $\mathrm{D}_{2}$ \\
\hline $\mathrm{ClO}_{2}(\%)$ & - & - & $22 \mathrm{KN}$ & - & 1 & 0.2 \\
$\mathrm{O}_{2}(\mathrm{psig})$ & - & 87 & - & 29 & - & - \\
$\mathrm{NaOH}(\%)$ & - & 1.5 & - & 1 & - & - \\
$\mathrm{H}_{2} \mathrm{SO}_{4}(\%)$ & - & - & 0.7 & - & - & - \\
Xylanase (\%) & 1 & - & - & - & & - \\
Consistency $(\%)$ & 10 & 10 & 8 & 8 & 10 & 10 \\
Temperature $\left({ }^{\circ} \mathrm{C}\right)$ & 25 & 95 & 60 & 75 & 75 & 75 \\
\hline
\end{tabular}




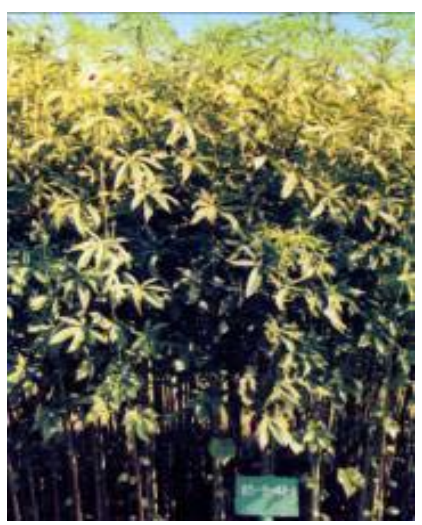

a). Plants of kenaf

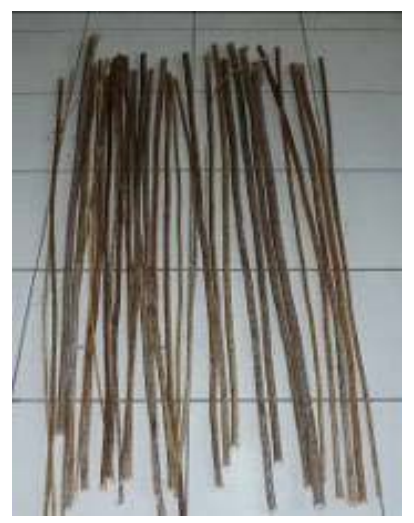

b). Stem of kenaf

Figure 1. Plants and Stem of Kenaf

has 5 class sizes. Kenaf chip used for cooking experiment is that retained in the screen of stage 2 and 3 with the chip size of around the length of $30-50 \mathrm{~mm}$ as shown in Figure 2.

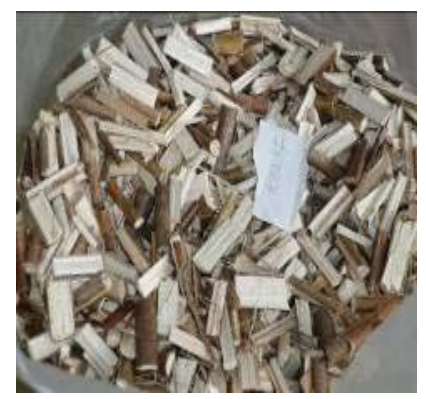

Figure 2. Kenaf Chips

Uniformity of the chip wood size that will be cooked is intended in order that in the cooking time and temperature applied could produce pulp with a homogeneous level of maturity (Casey, 1980). When the size of kenaf chip is smaller, it will cause the pulp produced is quite mature. Conversely, if the size of kenaf chips is larger, it can cause some chip is immature (Casey, 1980). Results of analysis of fibre morphology and chemical components of kenaf can be seen in Table 2 and Table 3, respectively.

Data obtained an experimental result of two replications. Felting power, stiffness, muhlstep ratio and runkel numbers are fibre properties to identify the extent of fibre able to be modified such as spun, untwisted fibre, and woven sheets made. If the value of runkel number is more than 1 (one), it indicates that types of non-wood fibres have thick walls, so the possibility of requiring greater energy milling or hard to be fibrillated. While kenaf fibre has the fibre length average of $2.59 \mathrm{~mm}$ for stem and $3.63 \mathrm{~mm}$ for bast and it is classified as the long fiber, fibre length $>1.60 \mathrm{~mm}$ (Casey, 1980).

From Table 3, it can be seen that holocellulose content of kenaf is $77.60 \%$ and $75.57 \%$ for bast and stem, respectivelly. Holocellulose is part of the fibre-free extractive and lignin, composed of cellulose and hemicelluloses, white to yellowish colour. Holocellulose content is the total carbohydrate or polysaccharides content in the raw materials. While the alpha cellulose content is $45.56 \%$ for bast and $39.46 \%$ for stem. This alpha cellulose content is high enough and it will produce high pulp yield (Casey, 1980).

Table 2 . Fibre Morphology of Kenaf

\begin{tabular}{|c|c|c|c|}
\hline No & Parameter & Stem & Bast \\
\hline 1. & $\begin{array}{l}\text { Fibre length }(\mathrm{mm}) \text { : } \\
\text { - minimum } \\
\text { - maximum } \\
\text { - average }\end{array}$ & $\begin{array}{l}0.84 \\
6.22 \\
2.59\end{array}$ & $\begin{array}{l}2.07 \\
6.81 \\
3.63\end{array}$ \\
\hline 2. & $\begin{array}{l}\text { Diameter }(\mu \mathrm{m}) \text { : } \\
\text { - outer } \\
\text { - in }\end{array}$ & $\begin{array}{l}28.44 \\
10.58\end{array}$ & $\begin{array}{c}23.78 \\
8.24\end{array}$ \\
\hline 3. & Wall thickness & 8.93 & 7.77 \\
\hline 4. & Runkel number & 1.69 & 1.89 \\
\hline 5. & Slimness & 91.07 & 152 \\
\hline 6. & Stiffness & 0.31 & 0.33 \\
\hline 7. & Flexibility & 0.37 & 0.35 \\
\hline 8. & Muhlstep ratio (\%) & 68.16 & 87.99 \\
\hline
\end{tabular}


Cellulose is a linear polysaccharide composed of units with ties anhydro-glucose $1-4$ b glucosidic that the hydrolysis in acidic conditions produces D-glucose. Cellulose is divided into three parts, namely $\alpha$ cellulose having a high molecular weight which is the part that stayed after the other cellulose dissolved on treatment with sodium hydroxide of $9.45 \%$. Dissolution will be developed with $17.5 \%$ sodium hydroxide, addition of $9.45 \%$ sodium hydroxide will produce soluble cellulose in the form of $\beta$-cellulose and $\gamma$-cellulose (Casey, 1980).

Table 3. Chemical Analysis of Kenaf

\begin{tabular}{clcc}
\hline No. & \multicolumn{1}{c}{ Parameter } & Bast & Stem \\
\hline 1. & Ash (\%) & 4.59 & 3.50 \\
2. & Lignin (\%) & 10.16 & 16.88 \\
3. & Extractive (\%) & 2.00 & 2.47 \\
4. & Holocellulose (\%) & 77.60 & 75.57 \\
5. & $\alpha$-cellulose (\%) & 45.56 & 39.46 \\
6. & Pentosan (\%) & 16.92 & 22.65 \\
7. & Solubility in cold water (\%) & 8.92 & 7.84 \\
8. & Solubility in hot water (\%) & 6.72 & 6.93 \\
9. & Solubility in NaOH (\%) & 25.36 & 28.51 \\
\hline
\end{tabular}

Extractive content contained in the raw materials are generally composed of fatty acids, resin, wax, gum and the other are volatile materials and un-volatile materials. Extractive (alcohol-benzene extract) is a substance in wood or pulp extracted by alcohol-benzene as a solvent, performed at the boiling point of solvent within a certain time. In general, non-wood containing low extractive will produce a clean pulp (Casey, 1980). Scanning Electron Microscope (SEM) picture of kenaf and their components that are inside can be seen in Figure 3. Figure 3 shows that the organic carbon component in the kenaf wood is $73.43 \%$ and the remaining is the other components.

\section{Pulp Making Process}

Data obtained from an experimental result of three replications. The initial phase of dissolving pulp making is the process of prehydrolysis of kenaf chip. This pre-hydrolysis process helps to facilitate the separation of cellulose fibres from lignin. kenaf pulp produced is still brown (unbleached). The results of the cooking non-wood of each prehydrolysis process can be seen in Table 4 .

Table 4 shows that pre-hydrolysis with water followed by the cooking process produce almost similar yield than that of pre-hydrolysis with acid. But the Kappa number is slightly higher than that of the pre-hydrolysis with acid.

Table 4. Result of Cooking Process

\begin{tabular}{cccc}
\hline No & Pre-hydrolysis & $\begin{array}{c}\text { Kappa } \\
\text { number }\end{array}$ & Yield (\%) \\
\hline 1. & Water & 22.81 & 50.03 \\
2. & $\mathrm{H}_{2} \mathrm{SO}_{4}$ & 19.81 & 50.00 \\
\hline
\end{tabular}

\section{Pulp Bleaching Process}

Bleaching of pulp was done by $\mathrm{XOD}_{0} \mathrm{E}_{0} \mathrm{D}_{1} \mathrm{D}_{2}$. Bleaching pulp at the stage of $\mathrm{X}$ using xylanase enzyme is known as bio-bleaching. Biobleaching can reduce chemical of bleaching so that it can reduce content of pollutants from pulp effluents (Noorbatcha et al., 2009; Rosli et al., 2005; Saleem et al., 2002). Pulp bleaching results are shown in Table 5 and Table 6.

The experimental results showed that the bleaching of kenaf pulp produce bleaching yield $>96 \%$. In this case, there is not much degraded cellulose by using xylanase enzymes (bio-bleaching). The brightness degree of dissolving pulp produced by the bleaching stage of $\mathrm{XOD}_{0} \mathrm{E}_{0} \mathrm{D}_{1} \mathrm{D}_{2}$ result is quite high i.e. above $86 \%$ ISO. This value is above the specifications of dissolving pulp for rayon grade (> $85 \%$ ISO) (SNI 0938-1989-A). Data obtained from an experimental result of three replications.

The chemical analysis results of dissolving pulp can be seen in Table 6. It shows that the dissolving pulp pre-hydrolyzed by acid and water has $\alpha$-cellulose content higher than $86 \%$ and it is a litle bit lower than the specifications as a raw material for the making of cellulose derivatives (SNI 0938-1989). Brightness and cellulose can be increased by reducing the content of pentosan. Pulp viscosity is very high, which means that the pulp bleaching process is not much cause degraded cellulose. Ash content in the bleached pulp is still quite high. To lower the ash content can be done by depithing process on its kenaf feedstock. 

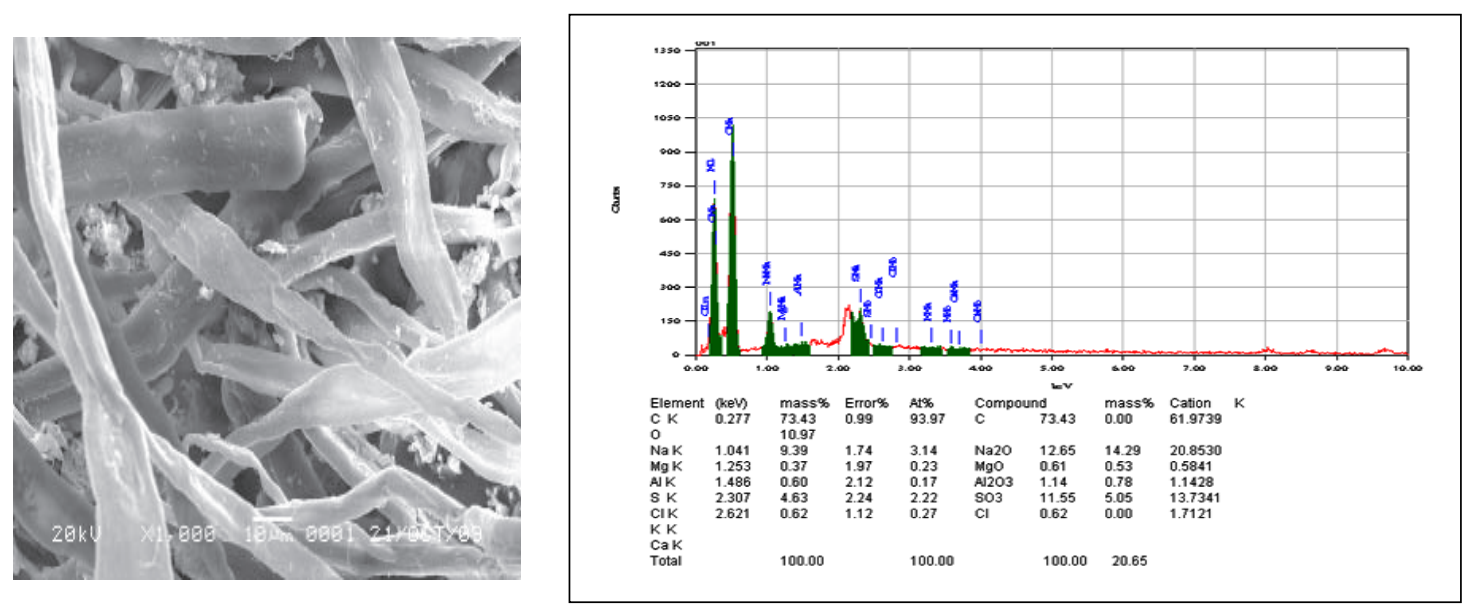

Figure 3. SEM Micrograph of Kenaf

Table 5. Result of Bleached Pulp

\begin{tabular}{lccccc}
\hline No & Prehydrolysis & $\begin{array}{c}\text { Yield } \\
(\%)\end{array}$ & $\begin{array}{c}\text { Kappa Number } \\
\text { after } \mathrm{O}_{2}\end{array}$ & $\begin{array}{c}\text { Brightness } \\
(\% \text { ISO })\end{array}$ & $\begin{array}{c}\text { Brightness of rayon } \\
\text { grade pulp }\end{array}$ \\
\hline 1. & Water & 96.92 & 9.58 & 86.23 & $>85 \%$ ISO \\
2. & $\mathrm{H}_{2} \mathrm{SO}_{4}$ & 98.73 & 8.69 & 86.27 & \\
\hline
\end{tabular}

Table 6. Chemicals Properties of Bleached Pulp

\begin{tabular}{lcccccccc}
\hline No & $\begin{array}{c}\text { Pre- } \\
\text { hydrolysis }\end{array}$ & $\begin{array}{c}\text { Moisture } \\
\text { content } \\
(\%)\end{array}$ & $\begin{array}{c}\text { Ash } \\
(\%)\end{array}$ & $\begin{array}{c}\alpha \text {-cellulose } \\
(\%)\end{array}$ & $\begin{array}{c}\text { Pentosan } \\
(\%)\end{array}$ & $\begin{array}{c}\text { Viscosity } \\
(\mathrm{cP})\end{array}$ & $\begin{array}{c}\text { Solubility } \\
\text { in } 10 \% \\
\mathrm{NaOH}\end{array}$ & $\begin{array}{c}\text { Solubility } \\
\text { in } 18 \% \\
\mathrm{NaOH}\end{array}$ \\
\hline 1. & $\mathrm{H}_{2} \mathrm{SO}_{4}$ & 4.92 & 0.78 & 86.36 & 14.97 & 29.06 & 10.93 & 7.65 \\
2. & Water & 4.61 & 0.77 & 86.71 & 14.71 & 27.55 & 10.34 & 7.33 \\
\hline
\end{tabular}
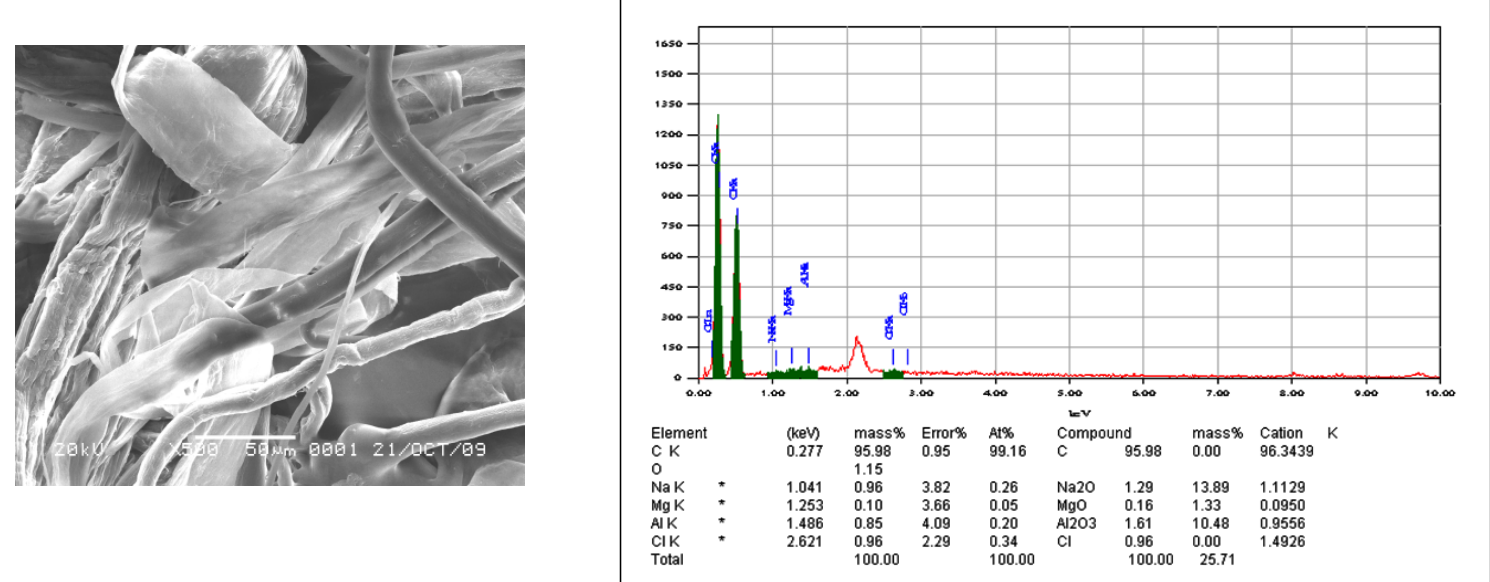

Figure 4. SEM Micrograph of Pulp Pre-Hydrolyzed by Acid 
Scanning Electron Microscope (SEM) picture of dissolving pulp pre-hydrolyzed by acids and the components therein can be seen in Figure 4. It shows that the components of organic carbon (C compound) in dissolving pulp made from kenaf is $95.98 \%$ and the rest is the other components that are higher than that kenaf itself. It shows that organic carbon (C compound) in dissolving pulp is higher than the raw material.

\section{CONCLUSIONS}

Kenaf fibre having an average fibre length of 2.59 to $3.63 \mathrm{~mm}$ fibres belonging to the long fibres. Holocellulose content of kenaf is $77.60 \%$ and $75.57 \%$ for bast and stem. Pre-hydrolysis with acid followed by the cooking process produce higher dissolving pulp yield, brightness, alpha cellulose, viscosity, alkali solubility and lower kappa number compared with prehydrolysis with water. Dissolving pulp having yield up to $98 \%$, the degree of brightness higher than $86 \%$ ISO, and alpha cellulose higher than $86 \%$ could be obtained by the bleaching stage of $\mathrm{XOD}_{0} \mathrm{E}_{0} \mathrm{D}_{1} \mathrm{D}_{2}$. Pulp viscosity is very high which means that the pulp bleaching process is not much cause degraded cellulose.

\section{ACKNOWLEDGEMENTS}

The authors are grateful to the colleagues at Center for Pulp and Paper (CPP) BandungIndonesia. Ministry of Industry for the support and the encouragement.

\section{REFERENCES}

Al-Dajani, W.W., Tschirner, U.W., 2008, Preextraction of hemicelluloses and subsequent kraft pulping. Part I: alkaline extraction, Tappi J 7.6: $3-8$

Casey, P.P., 1980. Pulp and Paper. Chemistry and Chemical Technology. Vol. 1. 3rd Ed. John Wiley \& Sons. New York

Christov, L.P. Akhtar, M., Prior, B.A. 1996. Biobleaching in Dissolving Pulp Production. Proceeding of the 6th International Conference on Biotechnology in the Pulp and Paper Industry: Advances in Applied and Fundamental Research. Vienna-Austria
Ibarra, D., Köpcke, V., Larsson, P.T., Jääskeläinen, A.S., Monica Ek., 2010. Combination of alkaline and enzymatic treatments as a process for upgrading sisal paper-grade pulp to dissolving-grade pulp, Bioresource Technology, 101 (19), 7416-7423

Indonesian National Standard (SNI) 0938-1989A. Pulp Rayon Biasa

Kumar, A., Kumar, R., 2009, Bio-bleaching of Wood Pulp: A Promising Aproach to protect the Environment from Chlorinated Pollutants. PSI2009/695.

Li, H., Saeed, A., Jahan, M.A., Ni, Y., Heinengen, A., 2010, Hemicellulose Removal from Hardwood Chips in the Pre-Hydrolysis Step of the Kraft-Based Dissolving Pulp Production Process, Journal of Wood Chemistry and Technology, 30, 48-60

Mossello, A. A., Ainun, Z. M. A., and Rushdan, I., 2009. Chemical, morphological, and technological properties of Malaysian cultivated kenaf (Hibiscus cannabinus L.) fibers. Kenaf Biocomposites, Derivatives \& Economics. Pustaka Prinsip Sdn. Bhd. Bandar Baru Seri Petaling, Kuala Lumpur

Noorbatcha, I.A., Hadi, M.A., Ismail, A.F., Salleh, H.M. 2009. In Silico Approach in Designing Xylanase for Biobleaching Industry. Journal of Applied Sciences, 9 (17):3184-3187

Pratiwi, W., Sugesty, S., Sudarmin, 2002, Peningkatan Kualitas Pulp Putih Serat Panjang dari Tanaman Kenaf Varietas Unggul, Laporan Akhir Penelitian, Balai Besar Pulp dan Kertas

Raghukumar, C., Muraleedharan, U., Gaud, V.R., Mishra, R. 2005. Xylanase of Marine Fungi of Potential use for Biobleaching of Paper Pulp. J. Ind. Microbiol. Biotechnology. 31-33

Rosli, Wan,W.D., Mazlan, I., Law, K.N., 2009, Effect of Kraft Pulping Variables on Pulp and Paper Properties of Kenaf Kraft Pulp. Cellulose Chem. Technol., 43 (1-3). 9-15

Russomanno, C., Sarkanen, S., 1998, Producing a True Lignin Depolymerase for Biobleaching Softwood Kraft Pulp. Forest Product Project Fact Sheet

Saleem, M., Akhtar, M.S., 2002, Biobleaching of Kraft Pulp by Xylanase Produced by Bacillus Subtilis. International Journal of Agriculture \& Biology, Vol. 4. No. 2 
Sudjindro, Teknologi untuk Mendukung Pengembangan Kenaf dan Sejenisnya, Prosiding Lokakarya Agribisnis Kenaf dan Sejenisnya, Malang, 7 Nopember 2001, Hal. $16-22$.

Sudomo, A., Permadi, P., Rahman, E., 2009. Kajian Control Silvikultur Hutan Tanaman Terhadap Kualitas Kayu Pulp, INFO TEKNIS, Vol. 5, No. 2, September 2007, Hal. 1 - 9.
Tremblay, L., Archibald, F., 1993, Production of Cloned Xylanase in B. cereus and its performance in kraft pulp-bleaching. Canadian J. Microbiol., 39:853

Viikari, L., Kantelinen, A., Sundquist, J., Linko, M., 1994, Xylanases in Bleaching: From an Idea ti Industry. FEMS Microbiol. Rev., 13: 335-350 